\title{
Flip-teaching methodology for university tourism guide and heritage interpreter courses
}

\section{Metodologia de ensino inversa de guia turístico universitário e cursos de intérprete de patrimônio}

DOI: $10.46814 /$ lajdv3n6-017

Recebimento dos originais: 01/11/2021

Aceitação para publicação: 07/12/2021

\author{
Maryland Morant-González \\ PhD. Associate Professor. \\ Universitat Politècnica de València. \\ Departamento de Ingeniería Cartográfica, Geodesia y Fotogrametría. \\ Camino de Vera s/n, 46022, Valencia, España. \\ E-mail: marmogon@cgf.upv.es \\ Nadia Alonso-López \\ $\mathrm{PhD}$. Professor. \\ Universitat Politècnica de València. \\ Departamento de Comunicación Audiovisual, Documentación e Historia del Arte. \\ Camino de Vera s/n, 46022, Valencia, España. \\ E-mail: naallo1@ har.upv.es
}

\begin{abstract}
Flip-teaching is a methodology in which the roles of lecturers and students are reversed, and effective learning is obtained by using ICT and encouraging independent study by students. This methodology inverts the traditional learning patterns and responsibilities of the lecturer, as well as the location, because university students obtain both theoretical and practical knowledge outside the classroom by working on contents provided by the lecturer. The aim of this research is to analyse how students on the Tourist Guide course of the Degree in Tourism at the Universitat Politècnica de València (UPV) design and produce subject materials using the flip-teaching method. In the university training on tourist guiding and heritage interpretation, students develop relevant skills, such as the ability to generate messages from a key idea to provoke emotions in visitors, and other communication skills to facilitate visits and improve user experiences. The results show a more intensive use of class materials by students.
\end{abstract}

Keywords: flip-teaching, learning method, experiential tourism, heritage interpretation, guide tourism and interpreters.

\section{RESUMO}

O ensino reverso é apresentado como um método no qual os papéis de professores e alunos são invertidos a fim de obter um aprendizado efetivo utilizando as TIC e abordando a atividade autônoma dos alunos. Esta metodologia não só inverte o esquema de aprendizagem tradicional em relação às tarefas e responsabilidades do professor, mas também os cenários, já que os estudantes universitários obtêm conhecimentos teóricos e práticos fora da sala de aula, através dos conteúdos fornecidos pelo professor e do trabalho contínuo. O objetivo desta pesquisa é analisar como os estudantes da disciplina Guias Turísticos da Licenciatura em Turismo da Universitat Politècnica de València projetam, 
produzem e produzem materiais sobre um tema específico usando o método de ensino inverso. No treinamento universitário de guias turísticos e intérpretes patrimoniais, são desenvolvidas habilidades relacionadas à interpretação patrimonial, tais como a capacidade de gerar mensagens baseadas em uma idéia central para provocar uma emoção nos visitantes, e outras habilidades de comunicação para facilitar a visita e melhorar a experiência do usuário. Os resultados mostram uma melhor utilização das aulas e dos materiais utilizados pelos alunos.

Palavras-chave: ensino de flip-teaching, método de aprendizagem, turismo experimental, interpretação do patrimônio, turismo-guia e intérpretes.

\section{INTRODUCTION}

The educational innovation carried out in the last decade within the framework of the European Higher Education Area (EHEA) has made lecturers consider new challenges to respond to new needs. New teaching-learning methods include active and renewed methodologies that encourage independent activity and practice by students, thus enabling a considerable reduction in the time dedicated to giving lectures (De Miguel, 2006; Huber, 2008; Labrador \& Andreu, 2008; Fernández, 2009; Leon et. al. 2010; Gijón \& Crisol, 2012; Huan, 2016; Pozo et al., 2020).

In accordance with the approaches that inspire the process of European convergence, university education must experience a profound renewal to change how information and knowledge are accessed (Salcines et al., 2019; López \& Bernal, 2019). The planning of the subjects must focus on the inclusion of a set of activities and tasks that have as goals: the tutoring of student learning; the acquisition of skills; and the achievement of learning objectives (Koster et al. 2005; De Juanas \& Fernández, 2008; Martínez, 2010; Nortvig, Petersen \& Hattesen, 2018; Awidi \& Paynter, 2019). In this process of change, independent learning is encouraged so that students become the protagonists by planning their work and time, and are also responsible for carrying out projects, thus encouraging an active role for students and greater effectiveness in the classroom (Iborra et al., 2016; Salcines et al., 2019; Pozo et al., 2020). Knowledge cannot be simply transferred, and it must be the students who construct the meaning of that knowledge (Weimer, 2013; Ramos \& Bongers, 2018) as a central part of the learning process (Bennet et al., 2011; Montanes et al., 2018). The lecturer becomes a mediator in the teachinglearning process who must use innovative training tools, and so becomes a 'cognitive companion' (Tedesco, 2010). Within the innovative training tools, new technologies play an essential role. We are examining active learning formulas where technology is an instrument of education - and not a learning outcome (Tourón, et al., 2014; Moreno et al., 2020).

Among other training tools, the flipped classroom is proposed as a method that can help in this process of change and the use of innovative methodologies for a more efficient use of time during lectures with active and participatory learning. This teaching-learning method reverses the traditional 
scheme so that tasks that were done at home are now done in the classroom and vice versa (Lage et al., 2000; Goodwing \& Miller, 2013; Sola et al., 2019). In short, we find ourselves before a constructivist model of active teaching, in which lecturer and student assume roles that differ from the traditional ones; the lecturer goes from being the 'sage on the stage' to being the 'guide on the side' (Jones, 2006).

The aim of this work is to show the results obtained in the implementation of the flipped classroom in the subject of Tourist Guides in the fourth year of the Degree in Tourism at the Universitat Politècnica de València (UPV) during the academic years 2015-2016, 2016-2017, 2017-2018 and 2018-2019 with a total of 70 students enrolled. This project has continued the work carried out in previous years in which the UPV began implementing innovative teaching methodologies with the introduction of dramatised routes (Teruel et al., 2014). The learning process was based on a flipped class project focused on the design and implementation of an interpretive route, with the aim of training students and future professionals in the process of planning the interpretation of heritage.

\section{THEORETICAL FRAMEWORK}

The teaching model that underlies the inverse class has always been used, for example, when lecturers asked for readings of texts that students had prepared for commenting on in the classroom. However, it was not until two decades ago that the flipped class methodology began to have greater impact and began to be applied in various university courses (Walvoord \& Johnson, 1998; Lage et al., 2000; Crouch \& Mazur, 2001). The term was consolidated in 2007 with professors Bergman and Sams from the Colorado Institute (USA), when they began to put the methodology into practice by recording videos and distributing them in their classes to help students who could not attend in person, thus responding to the training needs of each student (Bergman and Sams, 2012).

From then to the present, despite maintaining the essence of the meaning of flipped classes as coined by these lecturers, the methodologies employed have advanced as changes in teaching models and technological advances have taken place.

Flip-teaching has various names and the most common are: Inverted Classroom (Lage et al., 2000; Gannod et al., 2008; Strayer, 2012); Classroom Flip (Baker, 2000; Stone, 2012; Albert \& Beaty, 2014; Kyu, et al., 2014); Flipped Learning (Tourón \& Santiago, 2015; Khadri, 2016; Huang, Foon \& Kwan, 2018; Lee, Park y Davis, 2018; Bognar, Sablic yŠkugor, 2019; Pozo et al., 2020; Moreno et al., 2020); and Flipped Classroom (Gerstein, 2011; Wagner, Laforge \& Cripps, 2013; Young et al., 2014; Long, Cummins \& Waugh, 2016; Sola et al., 2016; Salcines et al., 2019). Despite the fact that the works published on the subject have used different terminologies, the authors agree that the techniques used in the classrooms are focused on independent work outside of class hours, with class hours for 
practical and cooperative activities. We are on the first step of an educational change that enables learning based on independent activities by students (Bergman \& Sams, 2014).

In flipped classes we work on how to manage the classrooms in a different way based on the principles of universal design for learning (UDL, 2018) that emphasise multiple means of expression, representation, and action. This change of work model is possible thanks to the support of information and communication technologies (ICT). Explanations are replaced by online materials of various types: short videos; blog readings; social networks; in addition to the recommended bibliography or presentations provided by the lecturer. It is important to have an online platform that allows direct and continuous contact between the student and lecturer. Class time is dedicated to practical activities in which the lecturer acts as a guide and the students learn by themselves (Sánchez et al., 2014; Fisher et al., 2017; Montanes et al., 2018).

Another of the fundamental characteristics of the inverse class is that it encourages curiosity and collaborative work on the part of students, giving greater weight to these aspects than in the traditional classroom (Brooks \& Brooks, 1999). Collaborative work is a teaching method based on teamwork that aims to achieve certain common goals, such as the appropriation of knowledge, and in which every member of the team is involved and responsible (Fortanet et al., 2013). The time spent in class is basically focused on group activities and work at home is more individual (although always directed).

Finally, it should be noted that this methodology offers the possibility of teaching students at their own pace, which means a greater personalisation. This model can be ideal for the development of the talent of the most capable (Tourón and Santiago, 2015).

\section{THE SUBJECT OF TOURIST GUIDES}

The Universitat Politècnica de València launched a pilot experience of flipped classes in the academic year 2014-2015. This method was a success and consolidated the international position of the UPV as one of the universities with the largest number of lecturers teaching flipped classes (288), with a total of 327 subjects registered in the programme (according to data from the 2019-2020 academic year). In addition to improving the quality of teaching through the use of networked educational resources to support classroom teaching, the UPV has sought to provide lecturers with the tools and methodology to help incorporate digital content in classroom subjects. The aim is to improve teaching and learning processes and so enable students to develop a more flexible and operational learning. Lecturers are instructed in flipped teaching through courses at the Institute of Education Sciences (ICE) of the UPV (Argiles, 2014). 
The flipped class experience presented in this paper has been developed in the subject of Tourist Guides, a fourth-year elective subject (semester A) in the Degree in Tourism Management course that offers 5 credits (classroom theory 2.75 credits, classroom practice 1.25 credits, and field practice 1 credit). It is taught by two lecturers, one of whom is co-author of this article. The flipped class methodology was used with the objective of deepening the design of an interpretive route framed in a Thematic Interpretation Programme (PIT).

Interpretive routes are the best approach for recreational activity at heritage spaces as they produce a minimal impact on resources and generate great enjoyment for visitors. These historical, social, or cultural routes are aimed at a general public, or a specific segment, to disseminate heritage. They involve direct contact between the public and the resources presented and this makes them effective activities (Morales, Guerra \& Serantes, 2009).

Interpretative routes can be prepared in a guided or self-guided approach, however, the best way to transmit the messages or topics is by employing specially trained guides with social and interpretative skills and the necessary support equipment. Many authors have supported the existence of this figure, arguing that the best interpretation of resources is that given in person (Tilden, 1957; Sharpe, 1982; Guerra \& Morales, 1996; Benton \& Knapp, 2004; Devesa \& Palacios, 2005; Ham, 2006; Hamish, 2009; Berckler, 2009; Paudel \& Nyanpaune, 2013; Houge \& Kerr, 2013; Pino, 2018).

The guide must make the experience unique, consolidate the messages, and allow for interaction and exchange with the heritage. It is about using communication methodologies in which it is necessary to know what to tell (messages that lead to the conservation of resources), how to tell it (in a pleasant, relevant, and orderly way), and to whom (active participation and adapting the route to the interests of the group). Interpretive routes are always thematic and must include a main message or idea, so it is essential to start from the design of PIT (a fundamental tool for heritage management). The mission of the PIT should be to enhance the value of heritage, whether natural or cultural, through knowledge and explanation of its historical, artistic, and/or naturalistic importance. This is achieved through the definition of three types of objectives: cognitive; attitudinal; and emotional.

Interpretation fundamentally addresses the aspects referred to in the art of explaining man's place in his environment as Ham (1992) states. Thanks to thematic interpretation, the development of attitudes, opinions, or beliefs is encouraged, and is therefore an important element in achieving the attitudinal objectives set out in a programme of this type. A planned interpretation programme plays a significant role in helping to control the impact of recreational activities on the resource by implementing appropriate management policies (Morales, 1998; Carrasco \& Rausell, 2005; Castells et al., 2008; Ham, 2013; Staiff, 2016). 
The PITs that are designed and implemented must have as a cognitive objective to publicise their heritage value and importance as natural or cultural heritage (tangible or intangible). The main emotional objective must be to provide the visitor with a memorable experience through the generation of sensations (Pike \& Ryan, 2004; Andrade, 2012; Viñals, 2017). The main attitudinal objective is to develop attitudes and behaviours of respect and appreciation for this heritage that induce visitors to support its conservation.

\section{METHODOLOGICAL APPLICATION OF THE FLIPPED CLASSROOM FOR THE SUBJECT OF TOURIST GUIDES}

The subject of Tourist Guides was organised using flipped classes and from a constructivist methodological perspective. Thus, it was structured in three phases: Bloom's taxonomy; Bruner's theory of learning and scaffolding by discovery; and collaborative work.

Bloom's taxonomy is the most commonly used system for identifying and prioritising student skills. The aim of this methodology is to classify learning objectives in terms of the development of skills organised in a pyramid from the most basic to the most complex: remembering; understanding; explaining; analysing; evaluating; and creating (Bloom et al., 1956). Bloom has been followed by numerous authors building on the pyramid base of skills (Andrés, 2005; Chatzopoulos, 2013; Martínez \& Márquez, 2014). In most recent tasks, the first two levels are worked on at home, while the remaining levels are moved into the classroom (Brame, 2013; Tourón \& Santiago, 2015).

Learning by discovery (Bruner, 1961) proposes a methodology in which students construct their own knowledge, based on learning by doing (exploring, investigating, and solving problems), as opposed to rote learning. The student is responsible for his own learning with activities inside and outside the classroom, while the lecturer directs the knowledge, combining techniques and methods focused on the student. We find ourselves with a learning process that follows the 'scaffolding principle' (the lecturer provides the necessary 'scaffolding' and removes it when no longer needed by the student). This methodology aims to strengthen the cognitive structure of the student, in which the tutorial interventions of the lecturer must maintain an inverse relationship with the student's level of competence in the task - the lower the level then the more help needed; and the higher the level, the less help is needed (Wood et al., 1976; Wells, 2001; Arias, 2008; Baro, 2011).

Collaborative work as a teaching strategy constitutes a model of interactive learning that invites building together and implies conjugating and sharing efforts and abilities in a consensual way (Guitert \& Jiménez, 2000; Maldonado, 2007; Chaljub, 2014). The work is built through interdependence with the members of the group, so that the goals are common to all. One of the fundamental strategies of collaborative work is to ensure that the formation of groups is heterogeneous in skills and abilities, 
with each member having part of the responsibility in relation to the actions to achieve the tasks assigned (individual and joint). Collaborative learning starts from teaching centred on the student, as it is promoted in constructivism. Students feel committed to the learning of others, through group work characterised by the contribution of all to the construction of knowledge (Collazos et al., 2014; Revelo et al., 2018).

Following these methodologies, firstly, the abilities to be covered within the Degree in Tourism of the UPV for the subject of Tourist Guides were identified. The abilities chosen were: a) acquire the ability to search for, assimilate, and share new knowledge by promoting personal and professional development in a self-organised way; b) manage cultural and natural heritage through techniques of assessment and identification of actors and elements; and c) implement an appropriate methodology to develop research and studies in the tourism sector.

The contents proposed revolve around: 1) analysis of the resources (natural and/or cultural) on which to carry out the interpretive route; 2 ) identification of the audience (final recipients of the route); 3) determination of the interpretive objectives (cognitive, emotional and attitudinal); 4) identification of the most characteristic features of the heritage to be interpreted (tangible and intangible attributes); 5) definition of the topic and message; 6) identification of the universal concepts; and finally, the development of the narrative script of the route.

In the development of these contents, the higher educational objectives of Bloom's taxonomy were followed as related to a greater degree of cognitive ability. Students carried out activities that enabled reflection and critical analysis, and led to the creation of an interpretative route.

To carry out the required work, the students were distributed in small groups (three maximum) to develop all the contents proposed in the design of the interpretative route selected by each group. The class time was dedicated to the practical development of the project. Each of the students had to critically analyse all the information available to them prior to the classes. Problems and doubts were solved with the lecturers who guided the work with instructions on what to do, using additional examples in those parts that needed more reinforcement.

In the subject, students produced creative solutions to the problems posed by making observations and formulating hypotheses for the design of an interpretative route. The students acquired the required knowledge on their own and the lecturers provided all the appropriate material to stimulate them, thus following Bruner's discovery learning methodology. The aim was to make the classes more dynamic for the individual and the group. Feedback was given in the classes on all the work and reinforcement was given where necessary.

The final result was the design of 20 interpretative routes that covered all the contents discussed in class and could also be put into practice. 
The evaluation consisted of the staging of the route by each of the groups for the rest of the class. This staging was recorded on video and students later carried out post-production, using a script that helped them identify and shape the phases of an interpretive route, following the contents worked on in class, but with a clear communicative intention through a narrative script structured in three main sections: introduction; plot; and conclusion. Likewise, this video production worked on communication techniques (oral and support) both on good practices and on aspects to be corrected regarding the heritage interpretation. Thus, in the presentation or introduction phase, the welcome and placement of the group and the guide were highlighted. The plot focused on the experiential aspects related to the activity, while the conclusion served to emphasise the main ideas discussed and somehow conclude by leaving a mark on the recipients, and thereby making them participants in helping to conserve the heritage interpreted.

\section{DISCUSSION AND CONCLUSIONS}

The development of flipped lectures for the subject Tourist Guides was possible thanks to PoliformaT, the online educational platform of the Universitat Politècnica de València that enables students to obtain the necessary material for the development and learning of a subject throughout the course (Lengua et al., 2019). This enabled students to feel more involved with the subject, because they could see the progress of their work from the beginning. In addition, it increased student participation in all activities and improved student-lecturer and peer communication. Group work was also encouraged, since $95 \%$ of these routes were designed by the students in pairs or groups of three.

Information and communication technologies (ICT) play a fundamental role in the development of this type of learning methodology, both for the ease of creating collaborative workspaces, and for the continuous communication with the lecturer and between students. The possibility of disseminating work done through social networks is an attraction for university students, thus increasing their communication skills. However, it should be borne in mind that to implement flipped lectures, universities must have the right types of tools. The ICT used in the subject in an appropriate and interactive way improved the performance of students, since the theory has been taken out of the classroom and the lecturer has become a facilitator of the learning process.

The learning was deeper when developing a specific project in which students had to contextualise, reflect, and build on their own knowledge - and so they were also more critical and creative in the design and execution of the interpretative route. There is no doubt that flipped learning is a good method to motivate and make students go deeper into a specific topic. Creative development is highly valued since students must be able to generate training materials that will serve other students 
in future experiences. Thus, the maximum level of learning can be reached when students are able to transmit their knowledge - and even more so if it is through videos.

Teamwork has enabled classes to better adapt to the rhythms of the students, as well as to encourage collaborative learning by improving the general classroom environment and relationships between students. However, the lecturer acquires a greater workload and must handle different learning rates depending on the progress experienced by each student. Grouping facilitates the good tutoring of students. The classes became an active workspace since every day they deal with different aspects of the design of the route for the project they have chosen. In the continuous evaluations, it was possible to verify that all the students covered all the proposed skills and learning objectives. Performance has been improved with respect to previous years in which this flipped class methodology was not applied. Likewise, student satisfaction, measured in terms of the evaluation of lecturer surveys regarding the specific implementation of flipped classes, shows a slight increase. These evaluations are carried out by the Institute of Educational Sciences (ICE) of the UPV, and the results are published at the end of each academic year for each subject. Student evaluations for the subject and materials used in the flipped classes (taught by *anonymised*) through PoliformaT can be seen in the following table:

Table 1. Student evaluations of *anonymised*'s flip-teaching.

\begin{tabular}{|l|l|l|}
\hline Academic Course & Overall Course Evaluation & Material Valuation Flip- Teaching \\
\hline $2015-16$ & 9.77 & 9.25 \\
\hline $2016-17$ & 9.64 & 8.95 \\
\hline $2017-18$ & 8.35 & 8.20 \\
\hline $2018-19$ & 9.55 & 8.75 \\
\hline
\end{tabular}

Source: ICE. Authors

Flipped classes can serve at the same time to prevent lecturers from working individually and in isolation, in addition to being able to share tasks and even subjects with other lecturers. The exchange of ideas, experiences, and materials can be easily carried out, which in turn, can serve to shape projects between different subjects. At the same time, flipped classes help meet the demands of each student by personalising education and adapting to individual needs. 


\section{REFERENCES}

Albert, M., \& Beatty, B. J. (2014). Flipping the Classroom Applications to Curriculum Redesign for an Introduction to Management Course: Impact on Grades. Journal of Education for Business, 89(8), 419-424. https://doi.org/10.1080/08832323.2014.929559

Andrade, M. (2012). La interpretación de la realidad del destino por parte de los turistas: evaluaciones cognitivas y afectivas. PASOS Revista de turismo y patrimonio cultural, 10(5), 477-494. https://doi.org/10.25145/j.pasos.2012.10.064

Andrés, C. (2005). La educación emocional en edades tempranas y el interés de su aplicación en la escuela. Programas de educación emocional, nuevo reto en la formación de los profesores. Tendencias pedagógicas, $10,107-123$.

Arias, W. L. (2008). Fundamentos del aprendizaje. Vicarte.

Argiles, A. (2014). Noticia UPV: Clase inversa o Flipped classroom | Universitat Politècnica de València. UPV. Retrieved from http://www.upv.es/noticias-upv/noticia-6615-clase-inversa-o-es.html Awidi, I. T., \& Paynter, M. (2019). The impact of a flipped classroom approach on student learning experience. Computers \& Education, 128, 269-283. https://doi.org/10.1016/j.compedu.2018.09.013

Baro, A. (2011). Metodologías activas y aprendizaje por descubrimiento. Revista Digital Innovación y Experiencias Educativas, 40, 1-11.

Baker, W. J. (2000). The «Classroom Flip»: Using Web Course Management Tools to Become the Guide by the Side. Communication Faculty Publications, 15, 9-17.

Benton, G., \& Knapp, D. (2004). Elements to successful interpretation: a multiple case of study of five National Parks. Journal of Interpretation Research, 9 (4), 9-26. https://doi.org/10.1177/109258720400900202

Bergmann, J., \& Sams, A. (2012). Flip Your Classroom. International Society for Technology in Education.

Bergmann, J., \& Sams, A. (2014). Dale la vuelta a tu clase: lleva tu clase a cada estudiante, en cualquier momento y cualquier lugar. SM.

Berkler, A. (2009). Putting out fires or building them? Interpretation as a management tool in region 3 of the U.S. fish and wildlife service's National Wildlife Refuge System. Stephen F. Austin State University.

Bloom, B., Engelhart, M., Furst, E., Hill, W., \& Krathwohl, D. (1956). Taxonomy of Educational Objectives: The Classification of Educational Goals, Handbook I: Cognitive Domain. David McKay.

Bognar, B., Sabli'c, M., \& Škugor, A. (2019). Flipped learning and Online Discussion in Higher Education Teaching. In C. Reidsema, L. Kavanagh, R. Hadgraft, \& N. Smith (Eds.), The Flipped Classroom: Practice and Practices in Higher Education (pp. 372-392). Springer Publishing.

Brame, C. (2013). Flipping the Classroom. Vanderbilt University.

Brooks, M. G., \& Brooks, J. G. (1999). The courage to be constructivist. Educational Leadership, 57 (3).

Bruner, J. S. (1961). The act of discovery. Harvard Educational Review, 31, 21-32. 
Carrasco, A., \& Rausell, P. (2005). Turismo, cultura y competitividad urbana: el caso de la ciudad de Valencia. IV Congreso Internacional de Cultura y Desarrollo: la cultura y su interacción con el turismo. El papel del patrimonio. La Habana, Cuba.

Castells, M.; Guerra, F. \& Sureda, J. (2008). Interpretación del patrimonio. Diseño de programas de ámbito municipal. UOC.

Chaljub, M. (2014). Trabajo colaborativo como estrategia de enseñanza en la universidad. Cuadernos Pedagógicos. 11 (22), 64-71.

Chatzopoulos, N. (2013). 4 Things To Considerer Begore You Flip Your Classroom. Edudemic. Retrieved from http://www.edudemic.com/2013/07/four-things-to-consider-before-you-flip-your-classroom/

Collazos, C. A.; González, C. S. \& García, R. (2014). Computer Supported Collaborative MOOCs: CSCM. Proceedings of the 2014 Workshop on Interaction Design in Educational Environments. Albacete, Spain.

Crouch, C. H. \& Mazur, E. (2001). Peer Instruction: Ten years of experience and results. American Journal of Physics, 69, 970-977. https://doi.org/10.1119/1.1374249

Devesa Fernández, M., \& Palacios Picos, A. (2005). Predicciones en el nivel de satisfacción percibida por los turistas a partir de variables motivacionales y de valoración de la visita. ICE, Revista De Economía, 1(821). 241-256. Retrieved from http://www.revistasice.com/index.php/ICE/article/view/768

De Juanas, A. \& Fernández, M.P. (2008). Competencias y estrategias de aprendizaje. Reflexiones sobre el proceso de cambio en el EESS. Cuadernos de trabajo social, 21, 217-230.

De Miguel, M. (2006). Modalidades de enseñanzas centradas en el desarrollo de competencias. Orientaciones para promover el cambio metodológico en el Espacio Europeo de Enseñanza Superior. Servicio de Publicaciones de la Universidad de Oviedo.

Fernández-Río, J. (2009). El modelo de Aprendizaje Cooperativo. Conexiones con el modelo comprensivo. In: A. Méndez (Coord.), Modelos actuales de iniciación deportiva. Unidades didácticas sobre deportes de invasión (pp. 75-99). Wanceulen.

Fisher, R., Ross, B., LaFerriere, R., \& Maritz, A. (2017). Flipped learning, flipped satisfaction, getting the balance right. Teaching \& Learning Inquiry, 5(2), 114-127. https://doi.org/10.20343/teachlearninqu.5.2.9

Fortanet, C. A., González, C., Mira, E. \& López, J.A. (2013). Aprendizaje cooperativo y flipped classroom. Ensayos y resultados de la metodología docente. XI Jornadas de Redes de Investigación en Docencia Universitaria. Universidad de Alicante.

Gannod, G. C., Burge, J. E., \& Helmick, M. T. (2008). Using the inverted classroom to teach software engineering. Proceedings of the 13th international conference on Software engineering - ICSE '08, 777786. https://doi.org/10.1145/1368088.1368198

Gerstein, J. (2012). The Flipped Classroom Model: A Full Picture. User Generated Education. Retrieved from https://usergeneratededucation.wordpress.com/2011/06/13/the-flipped-classroom-model-a-fullpicture/

Guijón, J. \& Crisol, E. (2012). La internacionalización de la Educación Superior. El caso del Espacio Europeo de Educación Superior. Revista de Docencia Universitaria, 10 (1), 389-414. 
Guerra, F., \& Morales, J. (1996). Uso público y recepción en espacios naturales protegidos. La atención a los visitantes reales y potenciales. Asociación para la Interpretación del Patrimonio.

Guitert, M. \& Jiménez, F. (2000). Trabajo cooperativo en entornos virtuales de aprendizaje. In: J.P. Duart, A. Sangrà, (Coords.), Aprender en la virtualidad, (pp. 113-134). Gedisa.

Goodwin, B. \& Miller, K. (2013). Research Says / Evidence on Flipped Classrooms Is Still Coming In. Technology-Rich Learning, 70(6), 78-80.

Ham, S. (1992). Environmental interpretation. A practical guide for people with big ideas and small budgets. Fulcrum Publishing.

Ham, S. (2006). La psicología cognitiva y la interpretación: síntesis y aplicación. Boletín de Interpretación, $15,14-21$.

Ham, S. (2013). Interpretation: Making a Difference on Purpose. Fulcrum Publishing.

Hamish Glen, M. (2009) Interpretación: ¿profesión, disciplina, arte o ciencia?. Boletín de Interpretación, 21, 28-33.

Houge, S. \& H. Kerr, J. (2013). Stress and emotions at work: An adventure tourism guide's experiences. Tourism Management, 36, 3-14. https://doi.org/10.1016/j.tourman.2012.10.018

Huan, C. (2016). A Study on Digital Media Technology Courses Teaching Based on Flipped Classroom. American Journal of Educational Research, 4(3), 264-267. https://doi.org/10.12691/education-4-3-6

Huang, B., Foon, K. \& Kwan, C. (2018). Investigating the effects of gamification-enhanced flipped learning on undergraduate students' behavioral and cognitive engagement. Interactive Learning Environments, 27 (8), pp 1-21. https://doi.org/10.1080/10494820.2018.1495653

Huber, G.L. (2008). Aprendizaje activo y metodologías educativas. Revista de Educación, 59, 59-81.

Iborra, M., Ramírez, E., Hug, J., Bringué, R., \& Tejero, J. (2016). Implementing the Flipped Classroom Methodology To the Subject "Applied Computing" of Two Engineering Degrees At the University of Barcelona. Journal of Technology and Science Education, 7(2), 119-135. https://doi.org/10.3926/jotse.244 Jones, V. (2006). How Do Teachers Learn to be Effective Classroom Managers? In C. M. Evertson \& C. S. Weinstein (Eds.), Handbook of classroom management: Research, practice, and contemporary issues, (pp. 887-907). Lawrence Erlbaum Associates Publishers.

Khadri, H.O. (2016). Flipped learning as a new educational paradigm: An analytical critical study. European Scientific Journal, 12 (10), 417-444. https://doi.org/10.19044/esj.2016.v12n10p417

Koster, B.; Brekelmans, M.; Korthagen, F., \& Wubbels, T. (2005). Quality requirements for teacher educators. Teaching and Teacher Education, 21 (2), pp. 157-173. https://doi.org/10.1016/j.tate.2004.12.004

Kyu, M., Kim, S., Kheraa, O. \& Getman, J. (2014). The experience of three flipped classrooms in an urban university: an exploration of design principles. The internet and higher education, 22, 37-50. https://doi.org/10.1016/j.iheduc.2014.04.003

Labrador, M.J. \& Andreu, M.A. (2008). Metodologías Activas. Universitat Politècnica de Valencia. 
Lage, M., Platt, G. y Treglia, M. (2000). Inverting the classroom: a gateway to creating an inclusive learning environment. The Journal of Economic Education, 31 (1), 30-43. https://doi.org/10.2307/1183338

Lee, J., Park, T., \& Davis, R. O. (2018). What affects learner engagement in flipped learning and what predicts its outcomes?. British Journal of Educational Technology. 1(1), 1-18. https://doi.org/10.1111/bjet.12717

Lengua, I., Peris, G., Dunai, L. \& Moncho, M. (2019). Enseñanza virtual. Plataforma Poliformat. In F. Sanz Adán \& J. Santamaría Peña (Coords.), La Transformación Digital en la Ingeniería Gráfica: Experiencias metodológicas para una enseñanzalaprendizaje innovadora de la Ingeniería Gráfica, (pp. 113-120). Universidad de La Rioja.

Long, T., Cummins, J. \& Waugh, M. (2017). Use of the flipped classroom instructional model in higher education: instructors' perspectives. Journal of Computing in Higher Education, 29, 179-200. https://doi.org/10.1007/s12528-016-9119-8

López, M. \& Bernal, C. (2019). El perfil del profesorado en la Sociedad Red: reflexiones sobre la competencia digital de los y las estudiantes en Educación de la Universidad de Cádiz International Journal of Educational Research and Innovation (IJERI). 11, 83-100.

Maldonado, M. (2007). El trabajo colaborativo en el aula universitaria. Universidad Pedagógica Experimental Libertador.

Martínez, V. (2010). La voz del profesorado universitario contratado. Un estudio sobre profesores asociados y contratados doctores de la Universidad Complutense de Madrid. Vivat Academia, 110, 30-52. https://doi.org/10.15178/va.2010.110.49-80

Martínez, D., Márquez, D.L. (2014). Las habilidades investigativas como eje transversal de la formación para la investigación. Tendencias Pedagógicas, 24, 347-360.

Montañés Muñoz, N., Sánchez Nácher, L., Fenollar Gimeno, O. Á., García Sanoguera, D. \& Quiles Carrillo, L. J. (2018). ¿Por qué es importante aplicar Docencia Inversa? ¿cómo hacerlo? Libro de Actas IN-RED 2018: IV Congreso Nacional de Innovación Educativa y Docencia en Red, 551-562. https://doi.org/10.4995/inred2018.2018.8596

Morales, J. (1998). Guía para la Interpretación del Patrimonio. El arte de acercar el legado natural y cultural al público visitante. Junta de Andalucía. Consejería de Cultura.

Morales, J., Guerra, F., y Serantes A. (2009), Bases para la definición de competencias en interpretación del patrimonio. Seminario Permanente de Interpretación del Patrimonio, Centro Nacional de Educación Ambiental, CENEAM. España.

Moreno-Guerrero, A.J., Romero-Rodríguez, J.M., López-Belmonte, J., \& Alonso-García, S. (2020). Flipped Learning Approach as Educational Innovation in Water Literacy. Water 2020, 12 (2), 574. https://doi.org/10.3390/w12020574

Nortvig, A.M., Petersen, A.K., \& Hattesen, S. (2018). A Literature Review of the Factors Influencing ELearning and Blended Learning in Relation to Learning Outcome, Student Satisfaction and Engagement. Electronic Journal of e-Learning, 16(1), 46-55. 
Paudel, S. \& Nyanpaune, G. P. (2013). The Role of Interpretative Tour Guiding in Sustainable Destination Management: A Comparison between Guided and Nonguided Tourists. Journal of Travel Research, 52 (5). 659-672. https://doi.org/10.1177/0047287513478496

Pino, N. (2018): La actualización de la preparación del guía de turismo para la interpretación del patrimonio. Revista Killkana Sociales, 2(4) 63-68. https://doi.org/10.26871/killkana_social.v2i4.375

Pike, S. \& Ryan, C. (2004). Destination positioning analysis through a comparison of cognitive, affective and conative perceptions. Journal of Travel Research, 42 (4), 333-342. https://doi.org/10.1177/0047287504263029

Pozo-Sánchez, S. López-Belmonte, J., Rodríguez-García A.M. \& López-Núñez, J.A. (2020) Teachers' digital competence in using and analytically managing information in flipped learning, Culture and Education, 32(2), 213-241. https://doi.org/10.1080/11356405.2020.1741876

Ramos, M. A. y Hernangómez, A. (2014). Actividades rítmicas (batuka y zumba) aplicadas al ámbito educativo de primaria y/o secundaria mediante metodología cooperativa. In C. Velázquez, J. Roanes y F. Vaquero (Coords.) Actas del IX Congreso Internacional de Actividades Físicas Cooperativas (pp. 468475). La Peonza.

Ramos, M.A. \& Bongers, A. (2018). Innovando en la motivación de los alumnos en las asignaturas de Economía. Egregius.

Revelo, O., Jimenez, J.A., \& Collazos, C.A. (2018). El trabajo colaborativo como estrategia didáctica para la enseñanza/aprendizaje de la programación: una revisión sistemática de literatura. TecnoLógicas 21 (41), 115-134.

Salcines-Talledo, I., Cifrián Bemposta, E., González-Fernández, N., \& Viguri Fuente, J. (2019). Estudio de caso sobre las percepciones de los estudiantes respecto al modelo Flipped Classroom en asignaturas de ingeniería. Diseño e implementación de un cuestionario. Revista Complutense De Educación, 31(1), 25-34. https://doi.org/10.5209/rced.61739

Sánchez, S. \& Martín, R. A. (2014). Formación docente para atender a la diversidad. Una experiencia basada en las TIC y el diseño universal para el aprendizaje. Revista de Ciencias de la Información, 26, 412429. https://doi.org/10.35742/rcci.2016.21(2).35-44

Sharpe, G. W. (1982). Interpreting the Environment. John Wiley and Sons.

Sola Martínez, T., Aznar Díaz, I., Romero Rodríguez, J.M. \& Rodríguez-García A.M. (2019). Eficacia del Método Flipped Classroom en la Universidad: Meta-Análisis de la Producción Científica de Impacto. REICE. Revista Iberoamericana sobre Calidad, Eficacia y Cambio en Educación, 17(1), 25-38. https://doi.org/10.15366/reice2019.17.1.002

Staiff, R. (2016). Re-imagining Heritage Interpretation: Enchanting the Past-Future. Routledge.

Stone, B. B. (2012). Flip Your Classroom to Increase Active Learning and Student Engagement. 28th Annual Conference on Distance Teaching \& Learning.

Strayer, J. F. (2012). How Learning in an Inverted Classroom Influences Cooperation, Innovation and Task Orientation. Learning Environments Research, 15, 171-193. https://doi.org/10.1007/s10984-012-9108-4

Tedesco, J. C. (2010). Prioridad de las políticas educativas. In E. Duro (Coord.), EducaciónSecundaria. Derecho, inclusión y desarrollo. Desafíos para la educación de los adolescentes (pp. 39-45). UNICEF. 
Teruel, L., Morant, M. \& Viñals, M.J. (2014). Dramatisation As A Teaching Method In University Programs For Tour Guides And Interpreters. Journal of International Education Research (JIER), 10 (5), 313-322. https://doi.org/10.19030/jier.v10i5.907

Tidel, F. (1957). Interpreting Our Heritage. University of North Carolina Press.

Tourón, J., Santiago, R., \& Diez, A. (2014). The Flipped classroom. Nurse Educator, 39(6), 321- 325. https://doi.org/10.21556/edutec.2018.65.1239

Tourón, J. \& Santiago, R. (2015). El modelo Flipped Learning y el desarrollo del talento en la escuela. Revista de Educación, 368, 196-231. https://doi.org/10.4438/1988-592X-RE-2015-368-288

UDL: The UDL Guidelines. (2018, 31 agosto). The UDL Guidelines.

Universitat Politècnica de València. (February 14, 2020). VI Jornada de Docencia Inversa en el Campus de Vera.

Viñals, MJ. (2017). Turismo Sostenible y Patrimonio. Herramientas para la puesta en valor y la Planificación. Universitat Politècnica de València.

Wagner, D., Laforge, P., \& Cripps, C. (2013). Lecture material retention: A first trial report on flipped classroom strategies in electronic systems engineering at the University of Regina. Proceedings of the Canadian Engineering Education Association (CEEA). https://doi.org/10.24908/pceea.v0i0.4804

Walvoord, E., \& Johnson, V. (1998). Effective grading: A tool for learning and assessment. Jossey-Bass.

Wells, G. (2001). Indagación dialógica. Hacia una teoría y una práctica sociocultural de la educación. Paidós.

Weimer, M. (2013). Learner - centered teaching: Five key changes to practice. Jossey -Bass.

Wood, D. J., Bruner, J. S., \& Ross, G. (1976). The Role of Tutoring in Problem Solving. Journal of Child Psychiatry and Psychology, 17, 89-100. http://dx.doi.org/10.1111/j.1469-7610.1976.tb00381.x

Young, T. P., Bailey, C. J., Guptill, M., Thorp, A. W., \& Thomas, T. L. (2014). The flipped classroom: A modality for mixed asynchronous and synchronous learning in a residency program. Western Journal of Emergency Medicine, 15(7), 938-944. https://doi.org/10.5811/westjem.2014.10.23515 